\title{
The 4.2 ka event in the central Mediterranean: new data from a Corchia speleothem (Apuan Alps, central Italy)
}

\author{
Ilaria Isola ${ }^{1}$, Giovanni Zanchetta ${ }^{1,2}$, Russell N. Drysdale ${ }^{3}$, Eleonora Regattieri ${ }^{2,3}$, Monica Bini ${ }^{1,2}$ Petra Bajo $^{4}$, \\ John C. Hellstrom ${ }^{4}$, Ilaria Baneschi ${ }^{5}$, Piero Lionello ${ }^{6}$, Jon Woodhead ${ }^{4}$, and Alan Greig ${ }^{4}$ \\ ${ }^{1}$ Istituto Nazionale di Geofisica e Vulcanologia, Pisa, Italy \\ ${ }^{2}$ Dipartimento di Scienze della Terra, University of Pisa, Pisa, Italy \\ ${ }^{3}$ School of Geography, University of Melbourne, Melbourne, Australia \\ ${ }^{4}$ School of Earth Sciences, University of Melbourne, Melbourne, Australia \\ ${ }^{5}$ Istituto di Geoscience e Georisorse-CNR, Pisa, Italy \\ ${ }^{6}$ Dipartimento Scienze e Tecnologie Biologiche e Ambientali, Università del Salento, Lecce, Italy
}

Correspondence: Ilaria Isola (ilaria.isola@ingv.it)

Received: 28 September 2018 - Discussion started: 10 October 2018

Accepted: 28 December 2018 - Published: 22 January 2019

\begin{abstract}
We present new data on the $4.2 \mathrm{ka}$ event in the central Mediterranean from Corchia Cave (Tuscany, central Italy) stalagmite CC27. The stalagmite was analyzed for stable isotopes $\left(\delta^{13} \mathrm{C}\right.$ and $\left.\delta^{18} \mathrm{O}\right)$ and trace elements $(\mathrm{Mg}, \mathrm{U}, \mathrm{P}$, $\mathrm{Y})$, with all proxies showing a coherent phase of reduced cave recharge between ca. 4.5 and $4.1 \mathrm{kaBP}$. Based on the current climatological data on cyclogenesis, the reduction in cave recharge is considered to be associated with the weakening of the cyclone center located in the Gulf of Genoa in response to reduced advection of air masses from the Atlantic during winter. These conditions, which closely resemble a positive North Atlantic Oscillation (NAO) type of configuration, are associated with cooler and wetter summers with reduced sea warming, which reduced the western Mediterranean evaporation during autumn-early winter, further reducing precipitation.
\end{abstract}

\section{Introduction}

A major and much-discussed example of a potential global "megadrought" and cooling during the Holocene occurred between ca. 4.2 and $3.9 \mathrm{ka} \mathrm{cal} \mathrm{BP}$ (the $4.2 \mathrm{ka}$ event hereafter) (Weiss, 2015, 2016). One of the best-documented case studies of the occurrence of the $4.2 \mathrm{ka}$ event in the Mediterranean basin comes from the RL4 flowstone from the Renella Cave (Drysdale et al., 2006; Zanchetta et al., 2016). The $\mathrm{Mg} / \mathrm{Ca}$ molar ratio, $\delta^{13} \mathrm{C}$ and organic matter florescence records obtained from RL4 flowstone calcite indicated a prominent reduction in cave recharge between ca. 4.3 and $3.8 \mathrm{ka} \mathrm{BP}$, corresponding to a pronounced drier period shown by the $\delta^{18} \mathrm{O}$ record. This was somewhat surprising considering the cave's geographic position. Renella Cave is located in a narrow valley draining the western side of the Apuan Alps (Fig. 1), a mountain belt that receives its precipitation from air masses of North Atlantic origin (Reale and Lionello, 2013) that interact with the most important cyclogenesis center of the Mediterranean region, the Gulf of Genoa (Fig. 1). The Gulf of Genoa cyclogenesis is most active between November and February (Trigo et al., 2002), but is a persistent feature over the whole year (Lionello et al., 2006). To a large extent, its location is determined by local topography, with the Alps (but also the Apuan Alps and Apennines, which bound the eastern side of the Gulf of Genoa) playing a major role by trapping air masses moving eastward and triggering Genoa cyclones (Trigo et al., 2002). The combination of these factors produces high precipitation amounts, locally reaching values up to $3000 \mathrm{~mm} \mathrm{yr}^{-1}$ over the Apuan Alps (Rapetti and Vittorini, 1994). Cyclogenesis in the Gulf of Genoa seems to be further maintained by cold advection of air masses on the western flank of the larger synoptic system towards the relatively warm temperatures over the Mediterranean Sea. Numerical experiments indicate that this is not a triggering factor, since Genoa cyclones are mainly topographically induced. It may, 


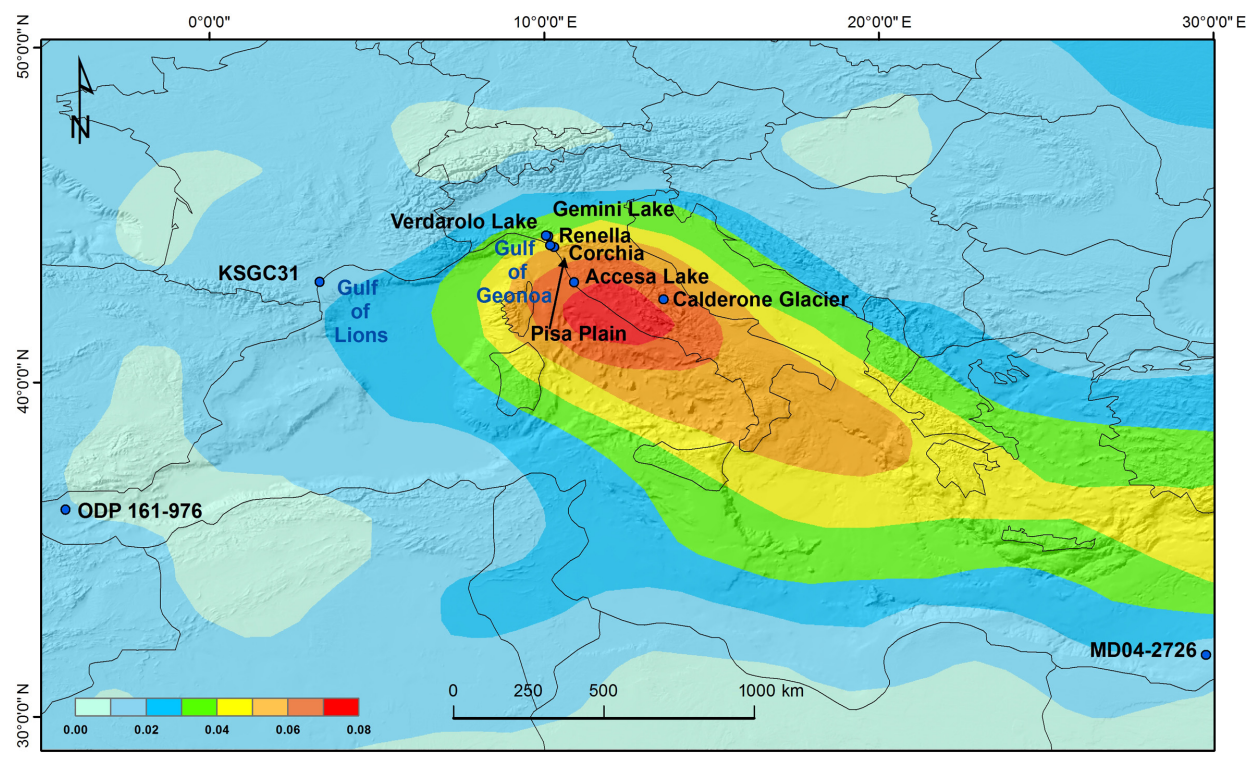

Figure 1. Location map of the sites discussed in the text. The figure shows the density track of winter storms according to ERA-Interim 1989-2009. Numerical values (number of cyclones/deg ${ }^{2}$ ) represent the average spatial density of cyclone centers in the winter season. Only cyclones with a minimum of 1-day duration and $5 \mathrm{hPa}$ of depth with respect to the background are included (modified after Lionello et al., 2012).

however, be crucial for determining the maximum intensity reached by the local low-pressure systems (e.g., McGinley and Zupanski, 1990; Trigo et al., 2002). The finding of a reduction of cave recharge over Renella Cave at the time of the $4.2 \mathrm{ka}$ event implies a substantial reduction in the advection of moisture from the North Atlantic and the cyclogenesis over the area, despite the fundamental orographic role exerted by the Apuan Alps. In this paper, we further explore the $4.2 \mathrm{ka}$ event in the Apuan Region, presenting new data (stable isotope, trace elements, $\mathrm{Mg}, \mathrm{P}, \mathrm{Y}$ and $\mathrm{U}$ ) from a Corchia Cave speleothem. Corchia Cave is located at a higher altitude compared to Renella Cave and it is characterized by a deeper and more complex plumbing system (Drysdale et al., 2004, 2006; Piccini et al., 2008; Zanchetta et al., 2007, 2014).

\section{Site description}

The Apuan Alps comprise intensively karstified marbles and metadolostones bounded by a Paleozoic basement mostly formed by phyllite, the latter considered substantially impermeable (Ciarapica and Passeri, 1994). The cave has been described in detail elsewhere (Drysdale et al., 2004; Piccini et al., 2008; Baneschi et al., 2011) and only general information is reported here. The stalagmite object of this study (stalagmite CC27) was collected from the "Galleria delle Stalattiti" (GdS; Fig. 2), which is located ca. $400 \mathrm{~m}$ below the surface at ca. $840 \mathrm{~m}$ a.s.l. The chamber has a constant mean annual temperature of $8.4^{\circ} \mathrm{C}$ and receives a recharge of $2500-3000 \mathrm{~mm} \mathrm{yr}^{-1}$ over an elevation range of ca. 1200 $1400 \mathrm{~m}$ (Drysdale et al., 2004; Piccini et al., 2008). Drip wa- ters in the chamber have a near-constant oxygen isotope composition $\left(\delta^{18} \mathrm{O}\right.$ : ca. $-7.4 \%$; Piccini et al., 2008; Baneschi et al., 2011), which is consistent with predicted averaged $\delta^{18} \mathrm{O}$ values of rainfall at this estimated recharge elevation range (Mussi et al., 1998; Drysdale et al., 2004). The carbon isotope composition $\left(\delta^{13} \mathrm{C}\right)$ of dissolved inorganic carbon (DIC) is similarly constant (ca. - $4 \%$; Baneschi et al., 2011) and reflects the low contribution of biogenic $\mathrm{CO}_{2}$ due to the thin vegetation cover, the long interaction with the marble bedrock and, possibly, shifts between closed- vs. opensystem conditions and sulfuric acid dissolution (Bajo et al., 2017). Several drips and pool waters analyzed in the GdS show very constant values for $\mathrm{pH}$, ion concentrations and isotopic composition, suggesting well-mixed waters and a stable, deep plumbing system (Baneschi et al., 2011).

\section{Material and methods}

CC27 is a $20 \mathrm{~cm}$ tall stalagmite collected in situ in the lower part of the chamber (Fig. 2). It was sectioned and polished, then sampled at $200 \mu \mathrm{m}$ increments along the growth axis for stable isotope analysis using a micromilling machine. Except for the interval between 58.3 and $64.7 \mathrm{~mm}$ from the top (for which every sample was analyzed), every third sample was analyzed. Isotope ratios were measured using a GV Instruments GV2003 continuous-flow isotope-ratio mass spectrometer at the University of Newcastle, Australia, using the method fully described in Tzedakis et al. (2018). Briefly, samples of 0.7 to $0.8 \mathrm{mg}$ were placed in septum-capped vials. The vials were purged with ultrahigh-purity helium 


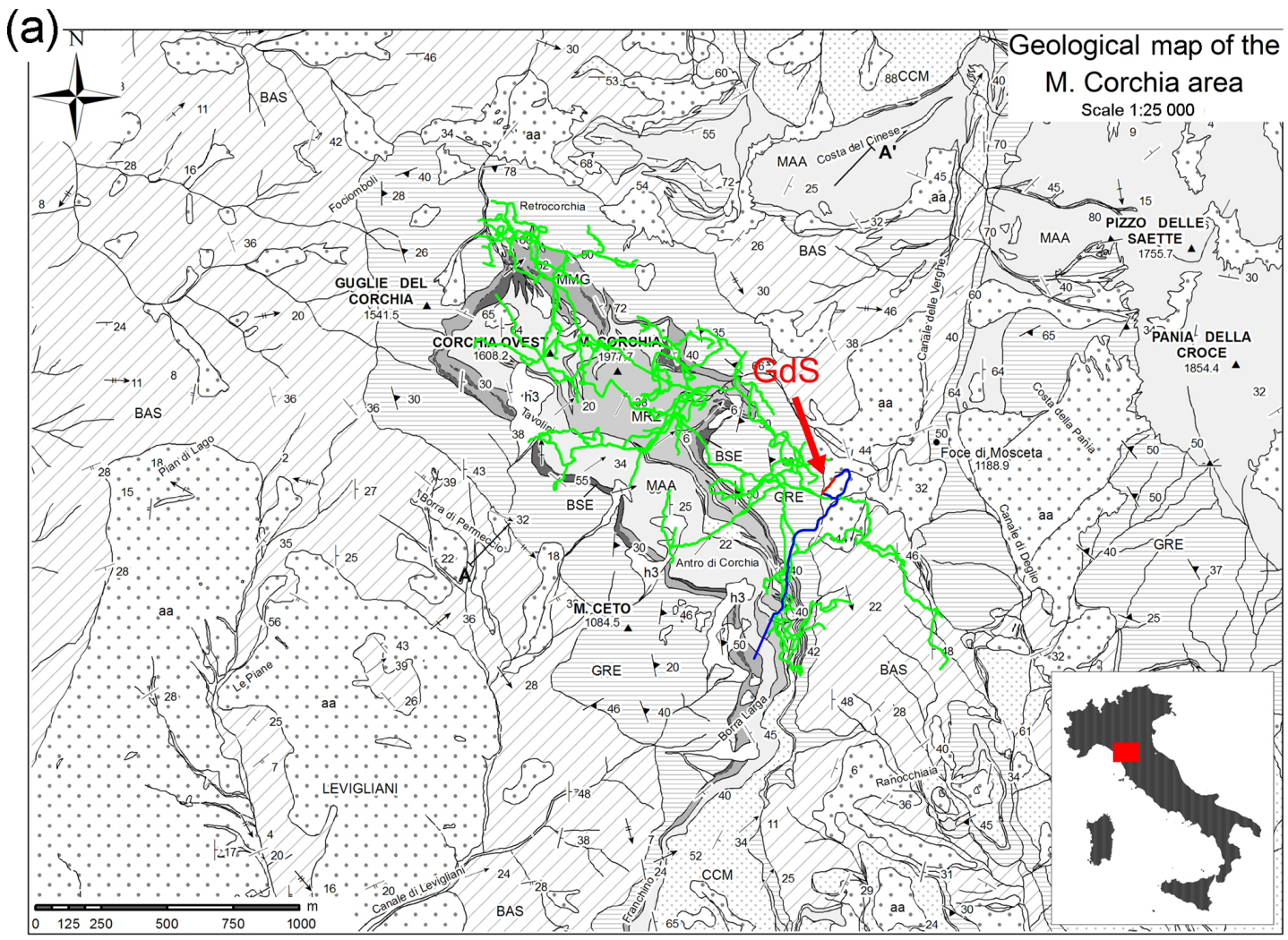

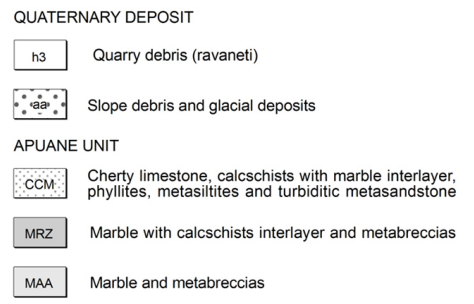

(b)

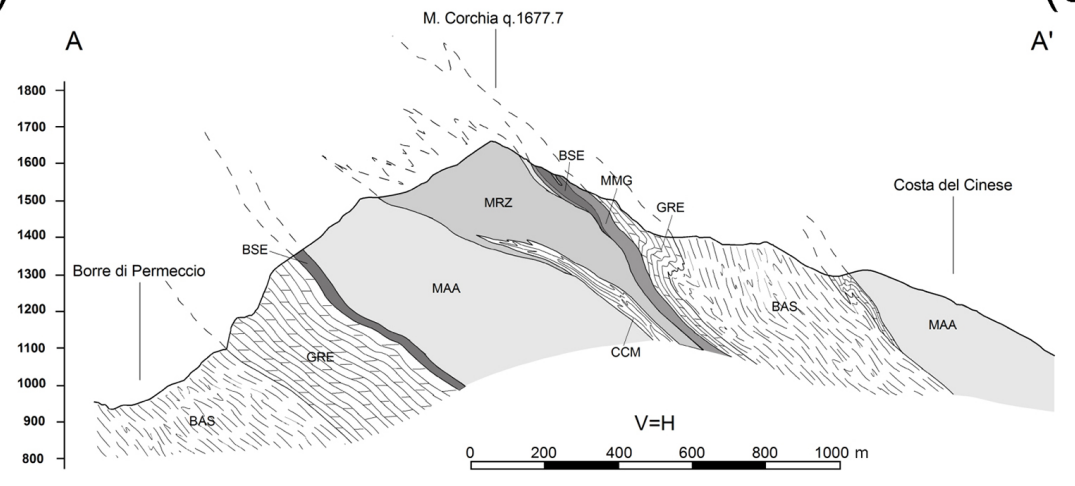

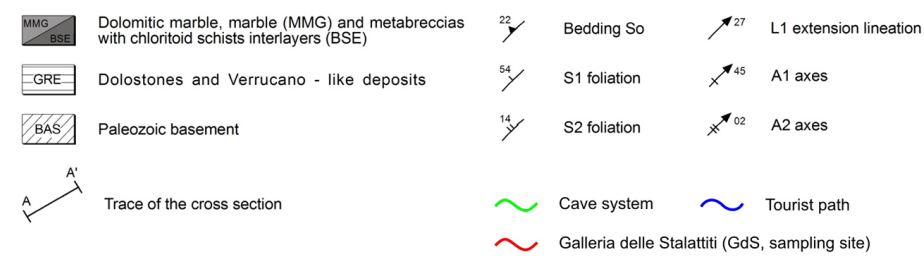

(c) $A^{\prime}$

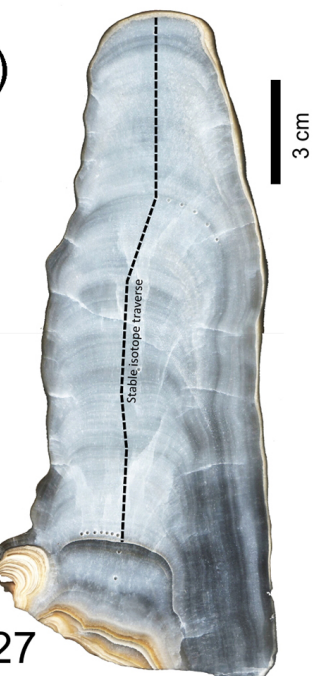

Figure 2. (a) Geological map of Mt. Corchia (modified after Piccini et al., 2008); (b) cross profile; (c) longitudinal section of the CC27 stalagmite. 


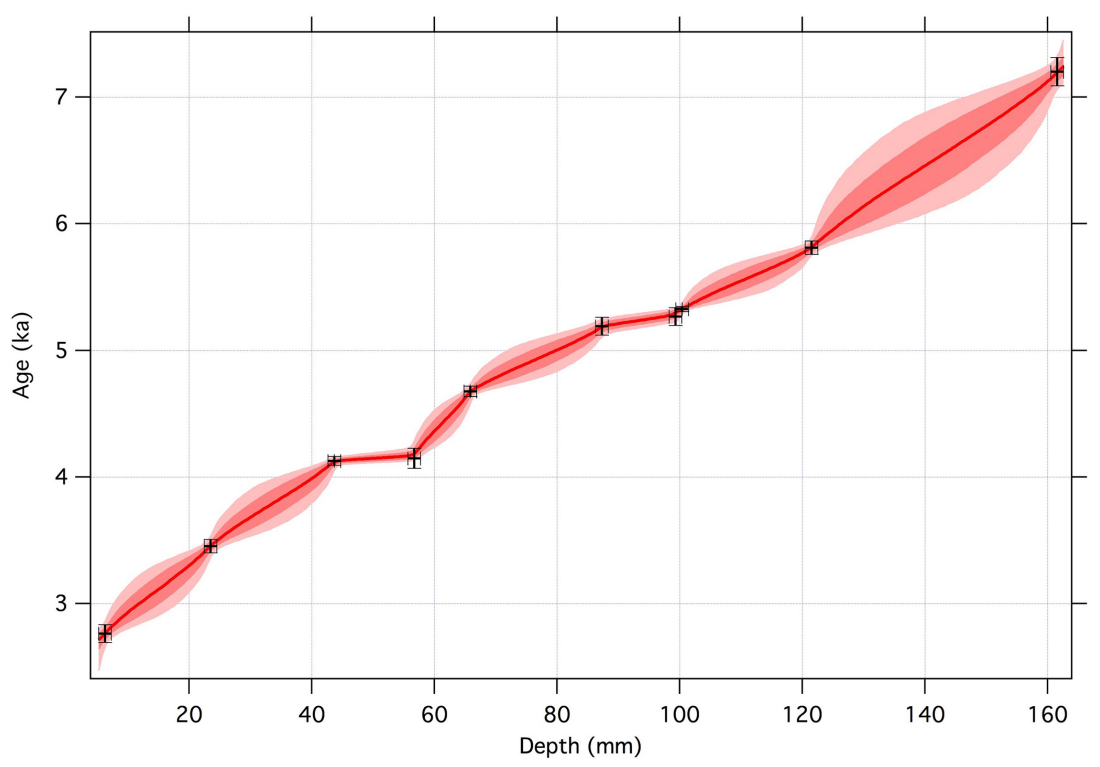

Figure 3. CC27 depth-age model. The outer shaded zones define the $95 \%$ uncertainties.

(99.9995\%) and then orthophosphoric acid (105\%) added at a temperature of $70^{\circ} \mathrm{C}$. All results are reported relative to the Vienna Pee Dee Belemnite (V-PDB) international scale. Sample results were normalized to this scale using an internal standard (NEW1: $\delta^{18} \mathrm{O}=-2.46 \%, \delta^{13} \mathrm{C}=2.40 \%$ ) previously calibrated using the international standards NBS18 and NBS-19. Analytical uncertainty for $\delta^{18} \mathrm{O}$ and $\delta^{13} \mathrm{C}$ was $0.09 \%$ and $0.05 \%$, respectively. Trace element analyses were carried out at the School of Earth Sciences, University of Melbourne, using a $193 \mathrm{~nm}$ ArF excimer laser-ablation system coupled to an Agilent 7700x quadrupole ICPMS. The Helex laser-ablation system (Woodhead et al., 2007) is driven by the GeoStar software (Resonetics). Prior to trace element determination, the sample was twice pre-ablated to clean the surface using a circular spot of $260 \mu \mathrm{m}$ diameter at a scan speed of $500 \mu \mathrm{m} \mathrm{min}^{-1}$ and a laser pulse rate of $15 \mathrm{~Hz}$. Element concentrations were measured from the pre-ablated surface using line scans parallel to the stalagmite growth axis. A main scan was obtained with a spot size of $55 \mu \mathrm{m}$, a scan speed of $50 \mu \mathrm{m} \mathrm{s}^{-1}$ and a laser pulse rate of $10 \mathrm{~Hz}$. To check for lateral data consistency two additional lowerresolution scans were performed $500 \mu \mathrm{m}$ apart and parallel to the main scan line. Quantification was carried out using the NIST SRM612 glass reference as an external standard. The standard was analyzed three times with the same spot size and a scan speed of $15 \mu \mathrm{m} \mathrm{s}^{-1}$. Raw mass spectrometry data were reduced using Iolite software (Hellstrom et al., 2008 ) and data were internally normalized to ${ }^{43} \mathrm{Ca}$. A total of 11 powder samples were taken for U-Th dating, which was performed at the University of Melbourne (Australia) by a $\mathrm{Nu}$ Instruments MultiCollector inductively coupled plasmamass spectrometer (MC-ICP-MS) according to the analytical method described in detail by Hellstrom (2003). The age model was derived in two steps following the method of Hellstrom (2003). First, a Bayesian technique was used to constrain consecutive age determinations that had overlapping uncertainty intervals, then a Monte Carlo procedure was used to randomize all age determinations at each iteration according to their isotope ratio uncertainties. The procedure then finds the best-fit monotonic series through these randomized ages using uncertainty-weighted least squares. This is repeated some thousands of times, and the revised ages and uncertainties for each age determination are obtained from the resulting data set. Here we present the data concerning the top part $(125 \mathrm{~mm})$ of the CC27 stalagmite.

\section{Results}

The corrected U-Th ages range from $2.67 \pm 0.70 \mathrm{ka}$ and $7.199 \pm 0.11 \mathrm{ka}$ (Table 1). Almost all ages are in stratigraphic order within the associated uncertainties, and only one age was rejected as an outlier. The calculated age-depth model ranges from 7.368 to $2.437 \mathrm{ka}$ (Fig. 3). Stable isotope values (average $-1.2 \pm 0.30 \%$ and $-5.0 \pm 0.19 \%$ or carbon and oxygen, respectively) are plotted vs. age in Fig. $4 ; \delta^{13} \mathrm{C}$ and $\delta^{18} \mathrm{O}$ show general covariant patterns, with higher values centered at ca. 5.9-5.7, 5.2-5.3, 4.5-4.1 and between ca. 2.8 and $2.7 \mathrm{kaBP}$. In the rest of the paper, we will focus on the 4.5-4.1 ka BP interval, which appears the most prominent and chronologically equivalent to the $4.2 \mathrm{ka}$ event (Fig. 4). Figure 4 shows also the $\mathrm{Mg}, \mathrm{U}, \mathrm{P}$ and $\mathrm{Y}$ elemental concentrations plotted versus age. In Table 2, the Pearson $r$ correlation coefficients between different trace element pairs are reported. Isotope ratios and $\mathrm{Mg}$ are well correlated (Fig. 4), with most of the lower isotope values corresponding to lower $\mathrm{Mg}$ values and vice versa. $\mathrm{U}$ displays an opposite behavior, 
Table 1. U/Th ages for the CC27 stalagmite.

\begin{tabular}{lrrrrrrr}
\hline Sample ID & Depth $(\mathrm{mm})$ & ${ }^{230} \mathrm{Th} /{ }^{238} \mathrm{U}$ & ${ }^{234} \mathrm{U} /{ }^{238} \mathrm{U}$ & ${ }^{230} \mathrm{Th} /{ }^{232} \mathrm{Th}$ & Uncorrected age & Corrected age & $2 \mathrm{~s}$ \\
\hline CC27 31,32,33 & 6.3 & 0.0162 & 0.6483 & 496.6459 & 2763 & 2761 & 70 \\
CC27-118 & 23.5 & 0.0202 & 0.6507 & 2624.0705 & 3443 & 3450 & 53 \\
CC27-220 & 43.7 & 0.0241 & 0.6517 & 2709.2452 & 4117 & 4124 & 35 \\
CC27-284 & 56.7 & 0.0244 & 0.6538 & 188.9949 & 4178 & 4145 & 77 \\
CC27-330 & 65.9 & 0.0273 & 0.6528 & 398.5427 & 4691 & 4674 \\
CC27 437 & 87.3 & 0.0302 & 0.653 & 3637.0706 & 5172 & 5188 \\
CC27-492 & 98.3 & 0.0312 & 0.6518 & 3175.7312 & 5372 & 5392 \\
CC27 497 & 99.3 & 0.0306 & 0.6522 & 4077.6739 & 5255 & 58 \\
CC27-502-503 & 100.4 & 0.0309 & 0.653 & 11788.6375 & 5324 & 71 \\
CC27-608 & 121.5 & 0.0337 & 0.6545 & 1613.9824 & 5788 & 5323 \\
CC27-809 & 161.9 & 0.0415 & 0.6537 & 7342.5966 & 7177 & 21 \\
\hline
\end{tabular}

Corrected U/Th ages for the CC27 stalagmite.

Table 2. Pearson correlation coefficients $r$ between elements calculated using 10-point running averages. All values are significant at $P<0.05$.

\begin{tabular}{lrrr}
\hline$r$ & $\mathrm{P}(\mathrm{ppm})$ & $\mathrm{Y}(\mathrm{ppm})$ & $\mathrm{U}(\mathrm{ppm})$ \\
\hline $\mathrm{Mg}(\mathrm{ppm})$ & -0.39 & -0.33 & -0.85 \\
$\mathrm{P}(\mathrm{ppm})$ & - & 0.60 & 0.32 \\
$\mathrm{Y}(\mathrm{ppm})$ & - & - & 0.29 \\
\hline
\end{tabular}

with a significant negative correlation with stable isotope values and $\mathrm{Mg}$ content ( $r=-0.85$; Table 2 ). The $\mathrm{P}$ and $\mathrm{Y}$ concentrations show a general positive correlation ( $r=0.60$; Table 2) and are weakly, though significantly, positively correlated with $\mathrm{U}$ ( $r=0.32$ and $r=0.29$ for $\mathrm{P}$ and $\mathrm{Y}$, respectively; Table 2) and negatively correlated with $\mathrm{Mg}(r=-0.39$ and -0.33 for $\mathrm{P}$ and $\mathrm{Y}$, respectively; Table 2 ). Both $\mathrm{P}$ and $\mathrm{Y}$ show the lowest values between 4.5 and $4.1 \mathrm{ka} \mathrm{BP}$ as well (Fig. 4). All values are significant at $P<0.05$.

\section{Discussion}

\subsection{Speleothem stable isotopes composition}

$\delta^{18} \mathrm{O}$ values of calcite $\left(\delta^{18} \mathrm{O}_{\mathrm{c}}\right)$ in the Apuan speleothems have been mostly interpreted on the premise that the $\delta^{18} \mathrm{O}$ in precipitation $\left(\delta^{18} \mathrm{O}_{\mathrm{p}}\right)$ in the western Mediterranean is dominated by the "amount effect"; i.e., a positive shift in $\delta^{18} \mathrm{O}_{\mathrm{p}}$ values corresponds to a lower precipitation amount and vice versa, with a gradient of ca. $-2 \%$ per $100 \mathrm{~mm}$ per month of precipitation (Bard et al., 2002). On the other hand, the temperature effect on precipitation (ca. $+0.3 \% 0^{\circ} \mathrm{C}^{-1}$; Bard et al., 2002) is almost equal but opposite in sign to the effect of a change in temperature on water-calcite isotopic fractionation (ca. $-0.2 \%{ }^{\circ} \mathrm{C}^{-1}$; Kim and $\mathrm{O}^{\prime}$ Neil, 1997). Thus, as a first-order interpretation, higher $\delta^{18} \mathrm{O}_{\mathrm{c}}$ values are considered to indicate a shift towards drier conditions, while lower values are associated with more humid periods (Drysdale et al., 2004; Zanchetta et al., 2007; Regattieri et al., 2014a). This "paradigm" holds for central and eastern Mediterranean speleothems (e.g., Bar-Matthews et al., 2003; Regattieri et al., 2018; Finné et al., 2017) and is also utilized for interpreting lacustrine marls, land snail shells and pedogenic carbonates in the region (e.g., Colonese et al., 2007, 2014; Regattieri et al., 2015, 2017; Boretto et al., 2017; Zanchetta et al., 2007, 2017). However, this picture can be complicated by changes in the seasonality of rainfall distribution. For instance, Longinelli et al. (2006) observed that years with an anomalous reduction of precipitation from spring to late autumn may have annual average isotopic values lower than expected, adding weight to the prevailing winter signal (i.e., more negative $\delta^{18} \mathrm{O}$ of precipitation; Dansgaard, 1964). This anomaly can be transferred to continental carbonates (Regattieri et al., 2015), and especially to Corchia speleothems, because cave recharge is mostly related to autumn-winter precipitation (Piccini et al., 2008). It has also been noted that changes in the isotopic composition of the source of vapor (Atlantic Ocean vs. Mediterranean Sea and changes in isotopic composition of the source) may have an additional effect (Bar-Matthews et al., 2000; Marino et al., 2015; Rohling et al., 2015). Despite these potential uncertainties, the interval with higher $\delta^{18} \mathrm{O}$ values at $4.5-4.1 \mathrm{ka} \mathrm{BP}$ should primarily indicate a reduction in cave recharge induced by a decrease in local precipitation, most probably related to winter, i.e., the season of maximum cave recharge (Piccini et al., 2008). This may also indicate a change in the proportion of cave recharge between the cold (autumn-winter) and the warm (spring-summer) half of the year.

In the western Mediterranean, and in temperate settings more generally, speleothem $\delta^{13} \mathrm{C}$ composition arises from the relative contribution of ${ }^{13} \mathrm{C}$-enriched $\mathrm{CO}_{2}$ derived from bedrock dissolution and ${ }^{13} \mathrm{C}$-depleted $\mathrm{CO}_{2}$ deriving from biological activity in the soil (e.g., Genty et al., 2001; Fairchild and Baker, 2012). Higher soil $\mathrm{CO}_{2}$ production occurs under wetter and warmer conditions, and thus $\delta^{13} \mathrm{C}$ values usually 


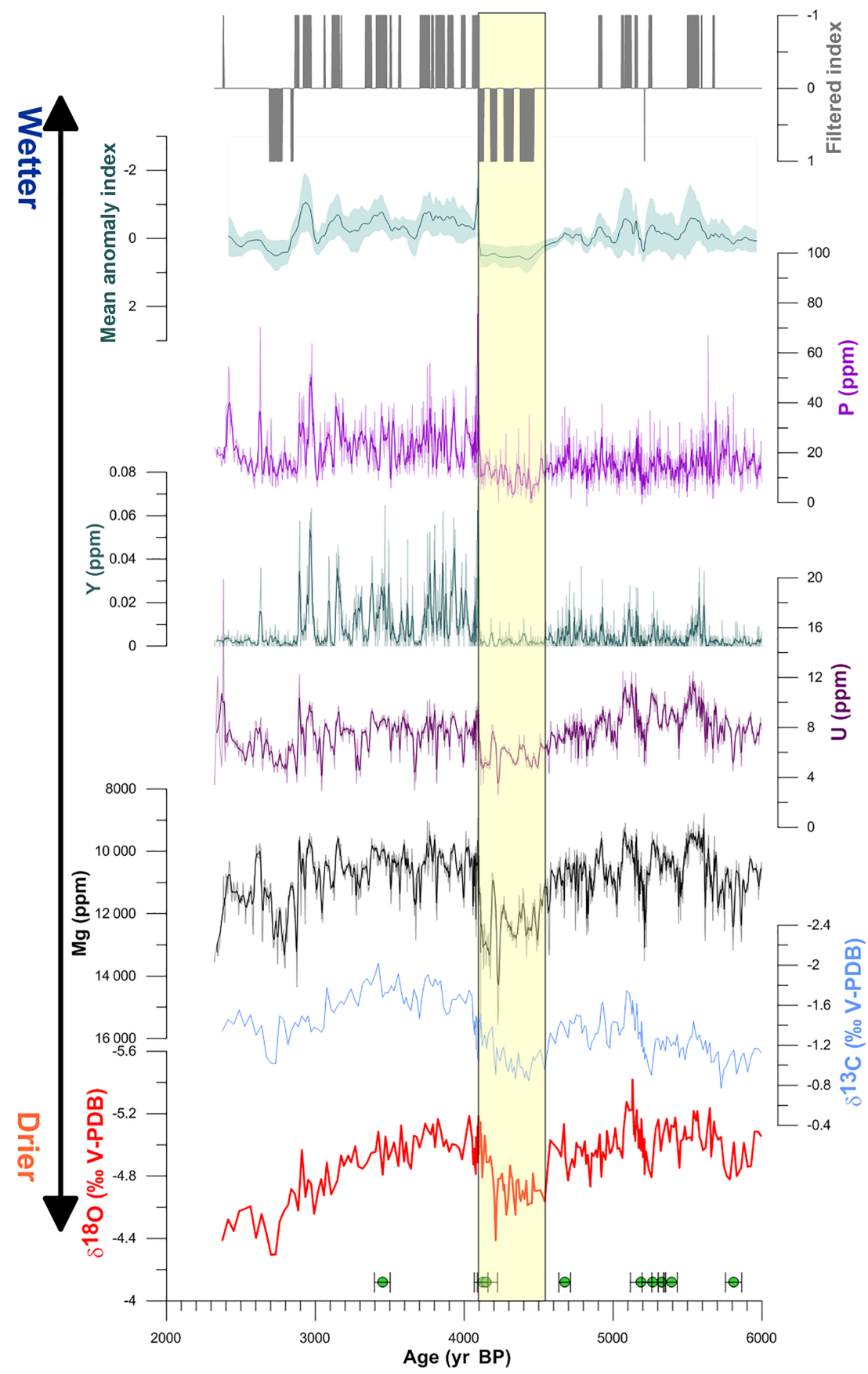

Figure 4. Time series of $\mathrm{CC} 27$ isotopes and trace elements. From the bottom: $\delta^{18} \mathrm{O}, \delta^{13} \mathrm{C}, \mathrm{Mg}, \mathrm{U}$, Y, P. Thick lines are 5-point running averages. Above the time series of the combined mean anomalies (referred to as MA time series in the main text) of trace elements (green line), error is expressed in standard deviation units (light blue strip), and on top is the square wave of the index of filtered anomalies (referred to as FI time series in the main text). Green dots represent U-Th ages, horizontal bars $2 \sigma$ errors. The yellow box represents the $4.2 \mathrm{ka}$ interval as recorded by $\mathrm{CC} 27$ proxies.

show a general negative correlation with the amount of rainfall, similar to the relationship already discussed for oxygen. Therefore, the concomitant increase in $\delta^{13} \mathrm{C}$ between 4.5 and $4.1 \mathrm{ka}$ BP corroborates the reduction in cave recharge associated with lower biological activity in the soil in the catch- ment, increasing residence time in the aquifer and increasing the dissolution of bedrock, including by sulfide dissolution (Bajo et al., 2016). 


\subsection{Trace elements}

Trace element data supply a fundamental additional control in the interpretation of secular variations in speleothem $\delta^{18} \mathrm{O}$ composition (e.g., Fairchild and Treble, 2009; Griffiths et al., 2010), which can complement and improve our partial knowledge on the long-term processes that drive the evolution of the oxygen isotopic composition of meteoric precipitation. $\mathrm{Mg}$ is generally transported to the speleothem in solution and, according to Fairchild et al. (2000), Mg/Ca changes in drip waters are due to four different factors, which may act concomitantly in Mg-rich dolomite bedrock (Fairchild and Treble, 2009; Regattieri et al., 2014b), as in the case of Corchia Cave. First, due to the rate of dolomite dissolution being slower than that of calcite (Fairchild and Treble, 2009), a longer water-rock interaction time would cause higher $\mathrm{Mg}$ concentrations in the drips. Second, prior calcite precipitation (PCP) may be important. This involves calcite precipitation in dewatered fractures along the flow path, upstream of the speleothem. Air present in fractures encourages $\mathrm{CO}_{2}$ degassing, calcite deposition and, indirectly, the enrichment of $\mathrm{Mg} / \mathrm{Ca}$ in the solution. This is because the partition coefficient of $\mathrm{Mg}$ is less than 1 (Morse and Bender, 1990). The occurrence of PCP is further highlighted by a positive covariance between $\mathrm{Mg}$ and $\delta^{13} \mathrm{C}$ because $\mathrm{CO}_{2}$ degassing causes ${ }^{13} \mathrm{C}$ enrichment in the solution and then in the speleothem calcite (e.g., Baker et al., 1997). Third, incongruent dolomite dissolution is plausible given the extensive presence of dolomite beds. Finally, there is the possibility of the selective leaching of $\mathrm{Mg}$ (Sinclair, 2011). The cumulative effect of these processes is an overall increase in $\mathrm{Mg}$ content in speleothem calcite during periods of lower cave recharge (i.e., under drier conditions; Hellstrom and McCulloch, 2000; Fairchild et al., 2006; McDonald et al., 2007; Regattieri et al., 2014b). P and $\mathrm{Y}$ are mostly transported as detrital phases (Borsato et al., 2007; Fairchild and Treble, 2009), which are a mixture of mineral particulate and organic colloids produced by the weathering of bedrock and leaching of soil (respectively), and deposited as microscopic particles concentrated in individual layers of calcite (Frisia et al., 2000) or as macroscopically visible clastic-rich layers, especially transported during flood events (Zhornyak et al., 2011). Entrainment of detrital phases in a very deep environment like GdS in Corchia is unlikely, as supported by the very pure calcite of the GdS speleothems (see low values in ${ }^{232} \mathrm{Th} /{ }^{230} \mathrm{Th}$ ratio; Table 1). For this reason, in our case the transportation of organic colloids is more likely. Studies of temperate ecosystems indicate that both $\mathrm{P}$ and $\mathrm{Y}$ in cave drip waters are principally bound to soil organic colloids and are indicative of infiltration rates, vegetation decomposition rates and soil development (Borsato et al., 2007; Treble et al., 2003). Thus, higher $P$ and $Y$ concentrations can be related to higher water infiltration rates and more developed soil and vegetation (i.e., warmer and wetter conditions), whereas lower values are indicative of lower infiltration and

less vegetation and soil productivity (i.e., drier and colder conditions; Borsato et al., 2007; Fairchild and Treble, 2009; Regattieri et al., 2016).

$\mathrm{U}$ concentrations in speleothems can be challenging to interpret. In near-neutral $\mathrm{pH}$ cave drip waters, stable uranyl $\mathrm{UO}_{2}^{2+}$ complexes form with carbonate, phosphate and organics (Osmond and Ivanovich, 1992; Treble et al., 2003). During rock alteration and pedogenesis in oxidizing conditions, tetravalent $\mathrm{U}(\mathrm{IV})$ changes to hexavalent $\mathrm{U}(\mathrm{VI})$, which is soluble in water (Ortega et al., 2005). U concentration in water may be influenced by changes in soil redox conditions. An increase in microbial respiration would lead to reduced oxidation within the soil, and this may cause less uranium to be oxidized to the hexavalent state and thus lower uranium concentrations in the seepage water (Osmond, 1980; Hellstrom and McCulloch, 2000). Soil and groundwater P concentrations may also influence the transport of $U$ through the strong affinity between phosphate and uranyl ions (Treble et al., 2003). After percolation through the karst network, U(VI) precipitates in calcite as $\mathrm{UO}_{2}^{2+}$, probably as a replacement of $\mathrm{Ca}^{2+}$. Experimental studies on synthetic calcite show that the partition coefficient of $\mathrm{U}$ between solution and solid varies between 0.06 and 1.43 (Day and Henderson, 2013), with no significant relationship with growth and drip rates or temperature. To disentangle the predominant environmental driver of $\mathrm{U}$ concentration in $\mathrm{CC} 27$, a comparison with the other proxies is useful. Our time series shows only a weak positive correlation between $\mathrm{U}$ and $\mathrm{P}$ (Table 2), suggesting that some of the $\mathrm{U}$ may be bound to phosphate and organic colloids. This is supported by Riotte et al. (2003), whose observations confirmed the possible control of colloids on the transport of $\mathrm{U}$ isotopes in freshwaters. A strong negative correlation between $\mathrm{U}$ and $\mathrm{Mg}$ is also observed (Table 2), whilst the general pattern of $\mathrm{U}$ changes appears to be negatively correlated with both $\delta^{13} \mathrm{C}$ and $\delta^{18} \mathrm{O}$ (Fig. 4), suggesting that higher-lower $\mathrm{U}$ concentration is related to wetter-drier conditions. This can suggest both a stronger leaching from rocks overlying $\mathrm{GdS}$ and hosting high U contents (e.g., Brecce di Seravezza, BSE in Fig. 2; Piccini et al., 2008) or a partition coefficient for $U$ in GdS water > 1; in this case changes in the $\mathrm{U}$ concentration of $\mathrm{CC} 27$ could be related to the degree of $\mathrm{PCP}$, as for $\mathrm{Mg}$ but in an opposite fashion. Overall, the most simple mechanism to control the U/Ca ratio would be the cave recharge and consequently leaching mechanism. Variations in soil redox conditions are likely to be negligible due to the thick bedrock cover over GdS. Indeed, the increase in soil biological activity, responsible for less oxidizing conditions and greater colloidal transport, would have been favored by wetter and warmer conditions, thus affecting $\mathrm{U}$ concentrations.

During the $4.2 \mathrm{ka}$ period (Fig. 4), lower P and Y likely indicate reduced colloidal production in soil and/or lower infiltration and transport into the cave. This is indicative of reduced vegetation development and water infiltration due to a reduction in precipitation. The latter also causes a reduction in $\mathrm{U}$ content. These patterns are in agreement with the 
concomitant increase in $\mathrm{Mg}$ related to the occurrence of PCP and thus to drier conditions, as testified also by the increase in $\delta^{13} \mathrm{C}$ related to soil $\mathrm{CO}_{2}$ supply but also to $\mathrm{CO}_{2}$ degassing upstream of feeding drip.

Therefore, the shifts observed in all trace elements (higher $\mathrm{Mg}$, lower U, P and Y) and in both stable isotope compositions (higher $\delta^{13} \mathrm{C}$ and $\delta^{18} \mathrm{O}$ ) together define a period of reduced cave recharge between 4.5 and $4.1 \mathrm{ka} \mathrm{BP}$ (Fig. 4). Assuming that the trace element behavior is related to hydrological variations as discussed before, we can combine the different individual trace element records to produce a composite mean anomaly (MA) time series and filtered index (FI) series (Regattieri et al., 2014b). This approach detects coherent variability across multiple speleothem properties, reducing the noise inherent in each series and highlighting the environmental signal. To produce the MA, the individual records were smoothed using a 10-point moving average, then normalized to produce correspondent time series of anomalies (i.e., deviations from a zero mean expressed in standard deviation units). Because the pattern of $\mathrm{Mg}$ is reversed with respect to the other trace elements, the latter were multiplied by -1 . Standard scores of the individual series were then averaged for each time increment to produce the MA wherein low (high) values correspond to relatively wetter (drier) conditions (Fig. 4). The result reveals a prominent drier interval in the MA between ca. 4.5 and $4.1 \mathrm{kaBP}$ (Fig. 4). In order to identify statistically significant events among these intervals, we then calculated the standard deviation of these four scores for each time increment. We thus set an upper (lower) threshold $\mathrm{MA}>(<) \mathrm{MA}_{\text {average }}+(-) \mathrm{SD}_{\text {average }}$ and such that any data point that satisfies these conditions is deemed "significantly dry" and "significantly wet" (respectively) relative to the mean state over the period. This statistical approach identifies patterns of simultaneous variations between different time series (Regattieri et al., 2014b) and, in particular, highlights the drier period between 4.5 and $4.1 \mathrm{ka} \mathrm{BP}$. This period of drier conditions overlaps, within uncertainties, the drier phases identified in the RL4 flowstone from Renella Cave (Fig. 5; Drysdale et al., 2006; Zanchetta et al., 2016). Figure 5 also shows the comparison between the CC27 multi-proxy record and that of CC26, a previously studied speleothem from the same chamber (Zanchetta et al., 2007; Bajo et al., 2016; Regattieri et al., 2014b, 2017; Tognarelli et al., 2018). Interestingly, the prominent shift in the $\delta^{18} \mathrm{O}_{\mathrm{c}}$ of CC27 is not apparent in the CC26 $\delta^{18} \mathrm{O}_{\mathrm{c}}$ record. However, during the 4.2 period, CC26 shows a pronounced increase in the $\mathrm{Mg} / \mathrm{Ca}$ ratio (Regattieri et al., 2014b), consistent with $\mathrm{Mg}$ (and other trace elements) variation measured in the $\mathrm{CC} 27$ record (Fig. 5). The difference between the $\mathrm{CC} 26$ and $\mathrm{CC} 27 \delta^{18} \mathrm{O}_{\mathrm{c}}$ records deserves further comment. For deep, large caves like Corchia, the complexity of the recharging system leads to the presence of different reservoir compartments characterized by different infiltration points and by different hydrological routings. In addition, GdS has the peculiarity to receive drip recharge from lateral paths because the chamber is overlain by the impermeable phyllitic basement (Piccini et al., 2008). This increases the drip-path complexity. Different paths and mixing of water may create small differences in the geochemistry of different drip points (e.g., Fairchild and Treble, 2009), though located in close proximity (i.e., in the same cave chamber). In addition, the steep slopes of Mt. Corchia can produce important changes in the mean altitudes of infiltration for different drips (up to several hundred meters over a relatively short distance), inducing the "altitude isotope effect" (Dansgaard, 1964). Mussi et al. (1998) derived an altitudinal effect of ca. $-0.15 \% \circ 100 \mathrm{~m}$ for the western Apuan slopes, which is significant considering the minor isotopic changes recorded in this cave during the Holocene (Zanchetta et al., 2007). Differences in the long-term isotopic records of different speleothems from the same chambers may be related to long-term drip-path evolution and, particularly, to changes in the mean altitude of recharge and/or to mixing of different reservoir compartments having different recharge areas. Another mechanism that can explain the different $\delta^{18} \mathrm{O}$ trends is the precipitation of calcite out of isotopic equilibrium conditions. Indeed, kinetic fractionation causes unpredictable isotopic enrichment (Mickler et al., 2006). However, this is unlikely for both CC26 and CC27, as they are both composed of monotonous columnar calcite (Bajo et al., 2016), the fabric thought to occur when speleothems are continuously wet and under relatively constant flow with calcite precipitation from fluids at or near isotopic equilibrium (e.g., Frisia et al., 2002; Frisia and Borsato, 2010).

\subsection{Other evidence of environmental changes over the Apennine and central Italy}

Environmental and climate change during the drier period identified over the Apuan Alps between ca. 4.5 and ca. $3.8 \mathrm{kaBP}$ (considering the whole range of ages present at Corchia and Renella caves) was previously reported for several sites on the Apennines and the surrounding coastal plains. In the central Apennines, geomorphological evidence of cooling and the reformation of Calderone Glacier were reported (Giraudi, 2004, 2005), and this event is stratigraphically constrained by the presence of Agnano Mt. Spina (ca. $4.4 \mathrm{ka} \mathrm{cal} \mathrm{BP}$ ) and Avellino (ca. $3.8 \mathrm{ka} \mathrm{cal} \mathrm{BP}$ ) tephra layers (Zanchetta et al., 2012, 2018). This suggests a reduction of either summer and/or winter temperature that may have caused a prevalence of snow precipitation during winter, higher winter accumulation and/or a reduced summer ablation. Cooler conditions during summer are also supported by fossil chironomid assemblages in the nearby northern Apennine Verdarolo and Gemini lakes (Figs. 1 and 6; Samartin et al., 2017). In further geomorphological evidence, a period of reduced alluvial activity is recognizable over the northern Apennines between ca. 4.4 and $3.6 \mathrm{ka}$ cal BP (Giraudi, 2014), consistent with drier conditions or rainfall patterns less prone to produce alluvial layers. Further, a general phase of re- 


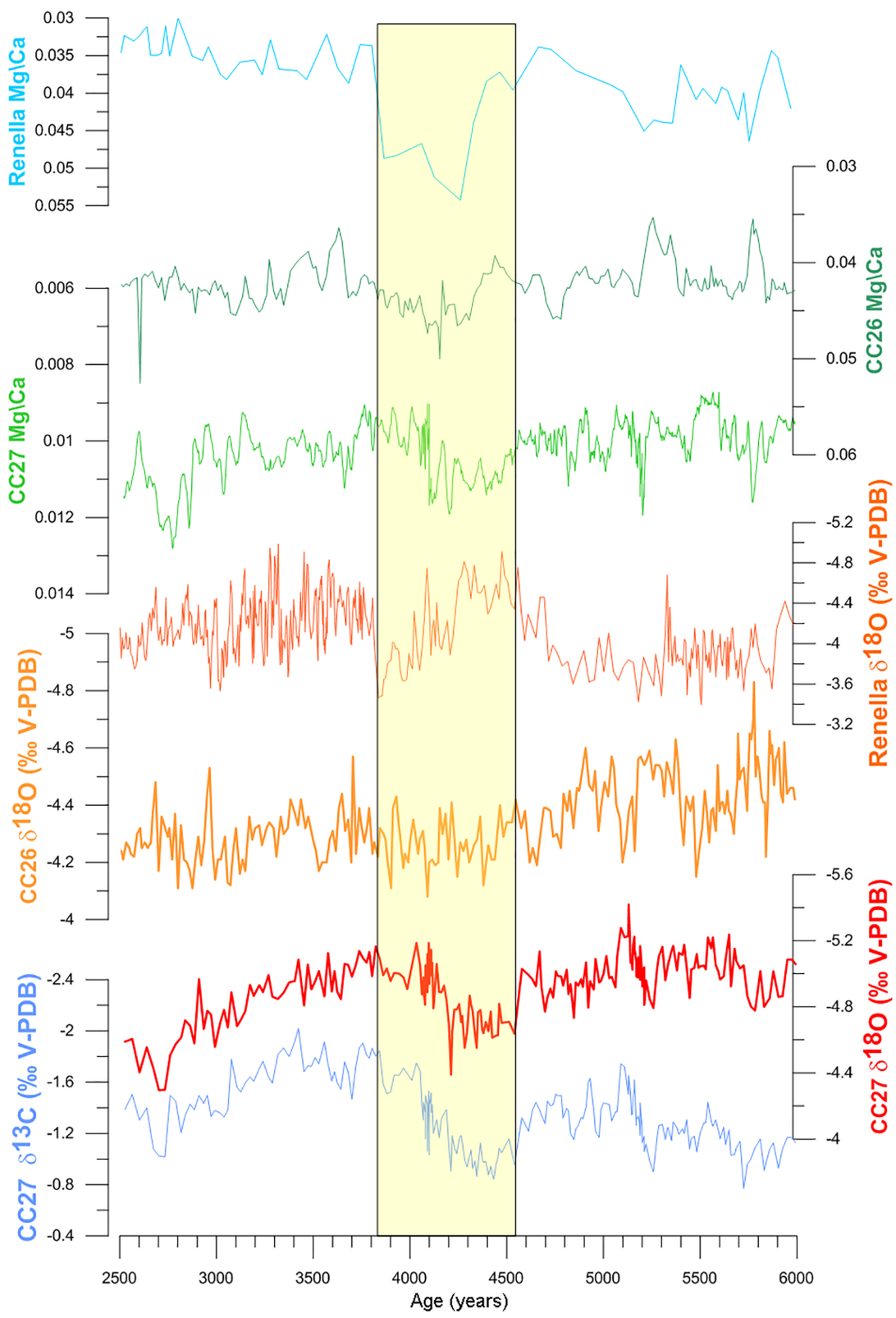

Figure 5. Comparison among CC27, CC26 and Renella proxies. From bottom: $\mathrm{CC} 27 \delta^{13} \mathrm{C}, \delta^{18} \mathrm{O}, \mathrm{CC} 26 \delta^{18} \mathrm{O}$, Renella $\delta^{18} \mathrm{O}, \mathrm{CC} 27 \mathrm{Mg} / \mathrm{Ca}$, $\mathrm{CC} 26 \mathrm{Mg} / \mathrm{Ca}$, Renella Mg/Ca. The yellow box represents the $4.2 \mathrm{ka} \mathrm{BP}$ interval as recorded by CC27 and Renella proxies. The Renella $\delta^{18} \mathrm{O}$ age model is adapted from Drysdale et al. (2019), and the $\mathrm{Mg} / \mathrm{Ca}$ age model is adapted from Drysdale et al. (2006).

duced valley sedimentary infilling occurs between ca. 4.2 and $3.6 \mathrm{ka}$ cal BP in the upper Turano River drainage basin, $60 \mathrm{~km}$ northeast of Rome, although the origin of this phase is interpreted to be related to a general phase of biostasy related to a well-developed vegetation cover preventing runoff and sediment transport (Borrelli et al., 2014). At lower altitudes, stratigraphic data from the Pisa alluvial plain (Fig. 1) indicate river channel avulsion (Sarti et al., 2015) during this period, suggesting that occasionally some large floods may have occurred. In contrast, Piccarreta et al. (2011) show an increase in alluvial events between ca. 4.3 and $4.1 \mathrm{ka}$ cal BP in some valleys of Basilicata (southern Italy). Quantitative reconstruction of climate parameters using pollen concentrations from Accesa Lake (southern Tuscany; Figs. 1 and 6; Peyron et al., 2013) shows reduced mean annual temperature over the considered period. Precipitation, reconstructed from the same record, shows high variability but no significant variations in mean annual values (Peyron et al., 2013). In terms of seasonality, the Accesa Lake records show a winter precipitation increase between 4.4 and $4.1 \mathrm{kacal} \mathrm{BP}$ and a decrease between 4.1 and $3.7 \mathrm{kacal} \mathrm{BP}$, as well as opposing summer precipitation patterns over both intervals 


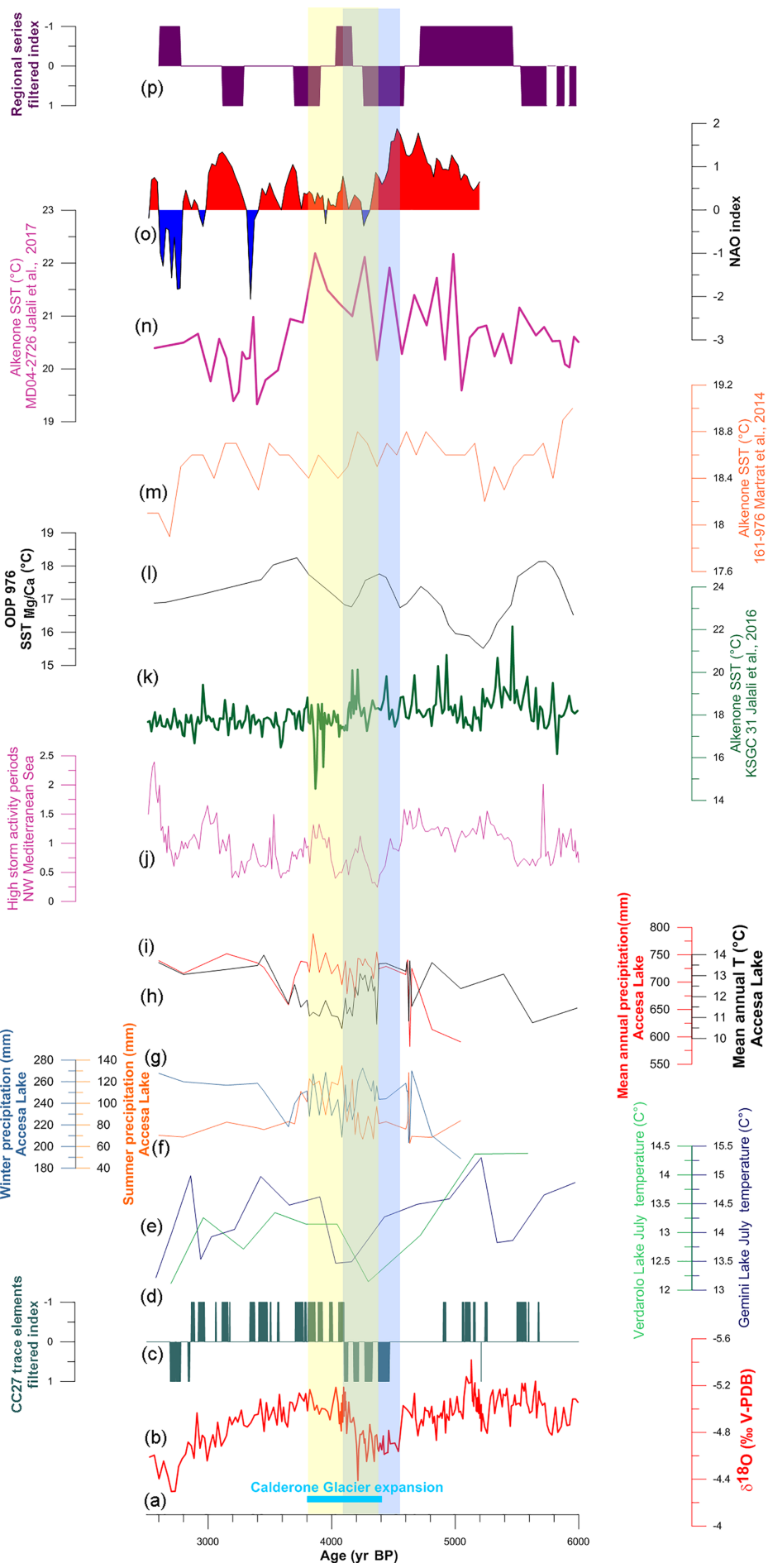

Figure 6. $\mathrm{CC} 27 \delta^{18} \mathrm{O}$ and trace element mean anomaly filtered index records compared with paleoclimate regional proxies. From bottom: (a) Calderone Glacier reactivation (Zanchetta et al., 2012); (b) CC27 $\delta^{18} \mathrm{O}$; (c) $\mathrm{CC} 27$ trace element mean anomaly filtered index; (d) chironomid midge assemblage temperature derived from Verdarolo Lake fossil (Samartin et al., 2017); (e) chironomid midge assemblage temperature derived from Gemini Lake fossil (Samartin et al., 2017); (f) Accesa Lake summer precipitation (Peyron et al., 2013); (g) Accesa Lake winter precipitation (Peyron et al., 2013); (h) Accesa Lake mean annual temperature (Peyron et al., 2013); (i) Accesa Lake mean annual precipitation (Peyron et al., 2013); (j) Gulf of Lions storm activity record (Sabatier et al., 2012); (k) alkenone temperature record from Gulf of Lions (Jalali et al., 2016); (l) SST Mg/Ca temperature record from Alboran Sea (Jiménez-Amat and Zahn, 2015); (m) SST alkenone temperature record from Alboran Sea (Martrat et al., 2014); (n) SST alkenone temperature record from MD04-2726 in the east Mediterranean (Jalali et al., 2017); (o) NAO index reconstruction (Olsen et al., 2012); (p) mean anomaly filtered index of the regional proxies as discussed in the main text. 
(Fig. 6). The winter precipitation reconstruction from Accesa may thus not be in agreement with proxy data from Corchia speleothems, which indicate a reduction in cave recharge. Overall, Apennines and central Italy records show some contrasting patterns. However, the interpretation of some proxies for environmental change in this region during the middle to late Holocene needs care for the potential human impact (Zanchetta et al., 2013). Indeed, this period corresponds to the beginning and definitive affirmation of the Bronze Age in Italy (Bietti Sestieri, 2010). The strong impact on the environment of the Bronze Age population makes it mandatory to consider each recorded environmental change as the complex result of both human activity and climate variability. This is particularly true for pollen records (Roberts, 2004; Fyfe et al., 2015), as Bronze Age communities strongly modified the composition of the vegetation. According to Borrelli et al. (2014), many Apennine catchments underwent a shift from generally prevailing biostasy to conditions of anthropic rhexistasy starting at around $4.2 \mathrm{ka}$.

\subsection{Regional comparison}

Looking at the wider regional palaeoclimate, both $\mathrm{Mg} / \mathrm{Ca}$ and alkenone sea-surface temperature (SST) data from the Alboran Sea (core ODP-976, SW Mediterranean; Fig. 1) show a temperature decrease around $4 \mathrm{kacal} \mathrm{BP}$ (Fig. 6; Jiménez-Amat and Zahn, 2015; Martrat et al., 2014). In the Gulf of Lions (NW Mediterranean; Fig. 1), the alkenone SST record from the KSGC31 core shows marked oscillations with minimum temperature values around $3.9 \mathrm{ka}$ cal BP (Jalali et al., 2016). Interestingly, and also from the Gulf of Lions, a record of storm activity shows a period of increased storminess between 4.4 and $4.05 \mathrm{kacal} \mathrm{BP}$ (Sabatier et al., 2012). High storm activity in the Gulf of Lions has been proposed to be related to cooling over the North Atlantic and the western Mediterranean (Sabatier et al., 2012). The alkenone SST signal from MD04-2726 in the east Mediterranean (Fig. 1) shows three marked oscillations between 4.6 and $4.1 \mathrm{ka} \mathrm{cal} \mathrm{BP} \mathrm{(Jalali} \mathrm{et} \mathrm{al.,} \mathrm{2017).}$

To perform a statistical even if simple analysis for the abovementioned regional time series (i.e., all the time series in Fig. 6 except the $\mathrm{CC} 27$ data), we used the same approach used for $\mathrm{CC} 27$ proxies. We derived the value for each point of each curve with 20-year binning, calculated the MA and, on the detrended MA curve, computed the FI square-wave curve, setting an MA threshold of +0.1 and -0.1 . The obtained FI curve (Fig. 6) represents "climatic anomaly" time series irrespective of the specific meaning. It shows between ca. 4.5 and $4.2 \mathrm{ka} \mathrm{BP}$ a well-expressed "negative" FI value, which roughly implies that this interval is a tendentially cold, dry and stormy period, which is comparable with MA for CC27.

\subsection{Synoptic atmospheric conditions}

We have already discussed the fact that speleothems over the Apuan Alps show consistent evidence of reduced cave recharge in a period ranging from ca. 4.5 to $3.8 \mathrm{ka} \mathrm{BP}$. This implies a reduction of cyclones of Atlantic origin (Reale and Lionello, 2013) and of secondary cyclogenesis over the Gulf of Genoa, considering the relation between cyclogenesis and rainfall in the area (Lionello et al., 2006; Reale and Lionello, 2013). A reduction in local cyclogenesis can be associated with a decrease in the arrival of North Atlantic air masses to the Gulf of Genoa and also reduced transit of North Atlantic cyclones (Reale and Lionello, 2013) and the reduction of vapor advection from the western Mediterranean, which acts as a moisture source for the central Mediterranean (Nieto et al., 2010). An important point to consider, however, is that it is not just a reduction in the cyclones reaching the Apuan Alps but also a reduction of precipitation associated with each single cyclone. Model simulations show that projected Mediterranean precipitation reduction in winter is strongly related to a decrease in the number of Mediterranean cyclones, but local changes in precipitation generated by each cyclone are also important (Zappa et al., 2015). For the central Apennines, winter precipitation is negatively correlated with the North Atlantic Oscillation (NAO) index (López-Moreno et al., 2011), with a negative NAO index associated with elevated precipitation during winter months. This is due to the lower pressure gradient between the Azores High and the Icelandic Low, which causes a southward shift in westerly trajectories, leading to increased penetration of moist air masses from the Atlantic to the Mediterranean and stimulating local cyclogenesis. The Genoa GNIP station shows a significant negative correlation between the amount of winter precipitation and the NAO index $(r=-0.74)$. At the same station, a significant positive correlation is found between $\delta^{18} \mathrm{O}_{\mathrm{p}}$ and the NAO index $(r=0.41)$ (Baldini et al., 2008). This is in agreement with rainfall amount and seasonality effects, as enhanced winter precipitation during NAO phases should be characterized by lower $\delta^{18} \mathrm{O}$ values. In central Europe, where the amount effect is negligible, a relatively strong positive impact of the winter NAO index on precipitation $\delta^{18} \mathrm{O}$ has been attributed to the higher frequency of cold easterly winds carrying ${ }^{18} \mathrm{O}$ depleted moisture during NAO negative phases compared to warmer westerly winds, which carry ${ }^{18} \mathrm{O}$-enriched moisture from the North Atlantic Ocean and Mediterranean Sea into central Europe during positive NAO winters (Baldini et al., 2008). However, persistent penetration of easterly moisture sources in the Gulf of Genoa is prevented by the Alpine ridge and there is a more important contribution of the local recycling of vapor from the Mediterranean Sea (Baldini et al., 2008). Thus, the correlation observed at the Genoa GNIP station suggests that during periods of reduced North Atlantic moisture (i.e., NAO positive phase causing northward shift of storm-track trajectories), precipitation from vapor of 
Mediterranean origin may dominate locally. The higher $\delta^{18} \mathrm{O}$ values should be in response to the effect of lower rainout of vapor masses (Celle-Jeanton et al., 2004) and the higher seawater isotopic composition of the Mediterranean compared to the North Atlantic (Pierre, 1999). From this point of view, the drier period recorded in the Apuan speleothems can be related to persistent positive NAO-like conditions, as invoked for some centennial- to multidecadal-scale climatic changes over the western Mediterranean (e.g., Fletcher et al., 2013; Zanchetta et al., 2014), including during the Medieval Climate Anomaly (Trouet et al., 2009). However, the reconstructed NAO index for the studied interval does not show a pronounced "positive mode" (e.g., Jackson et al., 2005; Olsen et al., 2012) and thus this mechanism is not an entirely satisfactory explanation (Fig. 6). Evidence from the tropics suggests that, at the time of $4.2 \mathrm{ka}$ event, there was a nearsynchronous disruption of the Indian and African summer monsoon systems (Fig. 6; Dixit et al., 2014; Welc and Marks, 2014) resulting from a southward shift of the Intertropical Convergence Zone (ITCZ) (Welc and Marks, 2014; Railsback et al., 2018). The position of the ITCZ and the resulting strength of the boreal summer monsoon both influence summer aridity and temperature in the Mediterranean region and are driven by atmospheric subsidence and strengthening of the summer high-pressure systems over the basin (Alpert et al., 2006; Eshel, 2002; Gaetani et al., 2011). A southward shift in the ITCZ can weaken summer aridity, producing milder (cooler) summer conditions over the Mediterranean. This is consistent with the precipitation reconstruction from Accesa Lake (Peyron et al., 2013), which suggests increasing rainfall during summer, and with a temperature reconstruction from chironomids indicating a reduction in summer temperature. On the basis of these observations we suggest that a weakening of high-pressure cells over the western Mediterranean during summer as the ITCZ shifts southward may have had a pronounced effect on Mediterranean Sea temperatures. Reduced seawater temperature at the end of summer can reduce evaporation during autumn-winter in the western-central Mediterranean Sea, causing reduced advection towards the central Mediterranean (Nieto et al., 2010) and decreased cyclogenesis in the Gulf of Genoa. This effect cannot be completely captured from available SST data, which record spring and/or annual average temperature and not specific late summer-autumn temperature (e.g., Fig. 6; Cisneros et al., 2016; Jalali et al., 2016; Bini et al., 2018). From the available data, it seems possible that a general reduction in precipitation, as reflected in the CC27 stable isotope and trace element data for the Apuan Alps, must have involved reduced advection of vapor masses during winter and a reduction in cyclogenesis over the Gulf of Genoa. However, during the summer, tropical weakening of the monsoon systems may have triggered cooler and wetter condition and this may have been one of the causes for the $4.2 \mathrm{ka}$ event.

\section{Conclusions}

The stable isotope and trace element composition of stalagmite CC27 from Corchia Cave records reduced moisture in northern Tuscany between 4.5 and $4.1 \mathrm{ka}$ BP. During this interval, increased $\delta^{13} \mathrm{C}$ and $\delta^{18} \mathrm{O}$ values occur at a time when $\mathrm{Mg}$ concentrations increase due to PCP, and Y and P concentrations decrease due to reduced infiltration, vegetation activity and soil development in the cave recharge area. Each of these changes is consistent with a shift to drier conditions. The decrease in $\mathrm{U}$ concentration can also be ascribed to reduced moisture. This period is, within age uncertainties, in agreement with trace element data from another speleothem from the same chamber (CC26; Regattieri et al., 2014b) and with the multi-proxy record from nearby Renella Cave (Drysdale et al., 2006; Zanchetta et al., 2016), which together provide robust evidence for a regional reduction in precipitation, in spite of some differences in chronology. These results imply a reduction of cyclones originating in the North Atlantic and of cyclogenetic activity in the Gulf of Genoa, probably due to a northward shift in westerly trajectories that reduced the transport of moist air masses from the North Atlantic and western Mediterranean. This suggests a positive NAO-like mode. Based on the available data in the region close to the Gulf of Genoa, a scenario of lower mean annual temperature, reduced precipitation during winter, and cooler and wetter summer conditions appears plausible. This is consistent with a southward shift of the ITCZ during summer, producing weaker high pressure over the western Mediterranean and reduced ocean surface warming, which dampens evaporation during autumn-early winter months. These results indicate that the synoptic processes behind the $4.2 \mathrm{ka}$ event involved changes not only in average conditions (as reported by the speleothem) but also significant changes at the seasonal scale, which need to be better investigated in future works.

Data availability. Data are available upon reasonable request.

Author contributions. II, GZ, RND, ER and MB conceived the paper; II and GZ wrote the paper with contributions from RND, ER and MB; II, GZ, RND, PB, JCH, IB, JW and AG contributed to the analytical work; PL contributed to the discussion on climate conditions over the area, and all the coauthors contributed to the scientific discussion on the conclusion of this paper.

Competing interests. The authors declare that they have no conflict of interest. 
Special issue statement. This article is part of the special issue "The 4.2 ka BP climatic event". It is a result of "The $4.2 \mathrm{ka} \mathrm{BP}$ Event: An International Workshop", Pisa, Italy, 10-12 January 2018.

Acknowledgements. We would like to thank two anonymous reviewers for their comments on this paper and helpful suggestions for improvements. We thank the Federazione Speleologica Toscana and Parco Regionale delle Alpi Apuane for supporting our work on Apuane speleothems. The analytical work presented here has been funded by the Australian Research Council Discovery Project DP160102969 awarded to Russell N. Drysdale, Giovanni Zanchetta, Eleonora Regattieri and John C. Hellstrom, and it is part of the ARCA project "Arctic: present climatic change and past extreme events" funded by the Italian Ministry of Education, Universities and Research (MIUR) awarded to Ilaria Isola. Part of this study has been developed within the framework of the project "Climate and alluvial event in Versilia: integration of Geoarcheological, Geomorphological, Geochemical data and numerical simulations" awarded to MB and funded by the Fondazione Cassa di Risparmio di Lucca. It is also part of "PRA-2018-41 Georisorse e Ambiente" funded by the University of Pisa.

Edited by: Harvey Weiss

Reviewed by: two anonymous referees

\section{References}

Alpert, P., Baldi, M., Ilani, R., Krichak, S., Price, C., Rodo, X., Saaroni, H., Ziv, B., Kishcha, P., Barkan, J., Mariotti, A., and Xoplaki, E.: Relations between climate variability in the Mediterranean region and the tropics: ENSO, South Asian and African monsoons, hurricanes and Saharan dust, in: Developments in Earth and Environmental Sciences, 4, 149-177, Elsevier, Amsterdam, 2006.

Baldini, L. M., McDermott, F., Foley, A. M., and Baldini, J. U.: Spatial variability in the European winter precipitation $\delta^{18} \mathrm{O}$ NAO relationship: Implications for reconstructing NAO-mode climate variability in the Holocene, Geophys. Res. Lett., 35, 4, https://doi.org/10.1029/2007GL032027, 2008.

Baneschi, I., Piccini, L., Regattieri, E., Isola, I., Guidi, M., Lotti, L., Mantelli, F., Menichetti, M., Drysdale, R. N., and Zanchetta, G.: Hypogean microclimatology and hydrogology of the 800$900 \mathrm{~m}$ asl level in the Monte Corchia cave (Tuscany, Italy): preliminary considerations and implications for paleoclimatological studies, Acta Carsologica, 40, 175-187, 2011.

Bajo, P., Hellstrom, J., Frisia, S., Drysdale, R., Black, J., Woodhead, J., Borsato, A., Wallace, M. W., Regattieri, E., and Haese, R.: "Cryptic" diagenesis and its implications for speleothem geochronologies, Quaternary Sci. Rev., 148, 17-28, 2016.

Bajo, P., Borsato, A., Drysdale, R. N., Hua, Q., Frisia, S., Zanchetta, G., Hellstrom, J. C., Woodhead, J., and Hendy, C.: Stalagmite carbon isotopes and dead carbon proportion (DCP) in a nearclosed-system situation: An interplay between sulphuric and carbonic acid dissolution, Geochim. Cosmochim. Ac., 210, 208227, 2017.
Baker, A., Ito, E., Smart, P. L., and McEwan, R.: Elevated ${ }^{13} \mathrm{C}$ in speleothem and implications for palaeovegetation studies, Chem. Geol., 136, 263-270, 1997.

Bard, E., Delaygue, G., Rostek, F., Antonioli, F., Silenzi, S., and Schrag, D.: Hydrological conditions in the western Mediterranean basin during the deposition of Sapropel 6 (ca. $175 \mathrm{kyr}$ ), Earth Planet. Sc. Lett., 202, 481-494, 2002.

Bar-Matthews, M., Ayalon, A., and Kaufmann, A.: Timing and hydrological conditions of sapropel events in the eastern Mediterranean, as evident from speleothems, Soreq cave, Israel, Chem. Geol., 169, 145-156, 2000.

Bar-Matthews, M., Ayalon, A., Gilmour, M., Matthews, A., and Hawkesworth, C. J.: Sea-land oxygen isotopic relationships from planktonic foraminifera and speleothems in the Eastern Mediterranean region and their implication for paleorainfall during interglacial intervals, Geochim. Cosmochim. Ac., 67, 3181-3199, 2003.

Bietti Sestieri, A. M.: L'Italia nell' età del Bronzo e del Ferro, Dalle palafitte a Romolo (2200-2700 a.C.), Carrocci Editore, Roma, 408 pp., 2010.

Bini, M., Zanchetta, G., Persoiu, A., Cartier, R., Català, A., Cacho, I., Dean, J. R., Di Rita, F., Drysdale, R. N., Finnè, M., Isola, I., Jalali, B., Lirer, F., Magri, D., Masi, A., Marks, L., Mercuri, A. M., Peyron, O., Sadori, L., Sicre, M.-A., Welc, F., Zielhofer, C., and Brisset, E.: The $4.2 \mathrm{kaBP}$ Event in the Mediterranean Region: an overview, Clim. Past Discuss., https://doi.org/10.5194/cp-2018-147, in review, 2018.

Boretto, G., Zanchetta, G., Ciulli, L., Bini, M., Fallick, A. E., Lezzerini, M., Andre, C. Colonese, A. C., Zembo, I., Trombino, L., Regattieri, E., and Sarti, G.: The loess deposits of Buca dei Corvi section (central Italy): revisited, Catena, 151, 225-237, 2017.

Borrelli, P., Domdey, C., Hoelzmann, P., Knitter, D., Panagos, P., and Schütt, B.: Geoarchaeological and historical implications of late Holocene landscape development in the Carseolani Mountains, central Apennines, Italy, Geomorphology, 216, 26-39, 2014.

Borsato, A., Frisia, S., Fairchild, I. J., Somogyi, A., and Susini, J.: Trace element distribution in annual stalagmite laminae mapped by micrometer-resolution X-ray fluorescence: implications for incorporation of environmentally significant species, Geochim. Cosmochim. Ac., 71, 1494-1512, 2007

Celle-Jeanton, H., Travi, Y., and Blavoux, B.: Isotopic typology of the precipitation in the Western Mediterranean region at three different time scales, Geophys. Res. Lett., 28, 1215-1218, 2004.

Ciarapica, G. and Passeri, L.: The Tuscan Nappe in Northern Apennines: data, doubts, hypotheses, Mem. Soc. Geol. It., 48, 7-22, 1994.

Cisneros, M., Cacho, I., Frigola, J., Canals, M., Masqué, P., Martrat, B., Casado, M., Grimalt, J. O., Pena, L. D., Margaritelli, G., and Lirer, F.: Sea surface temperature variability in the central-western Mediterranean Sea during the last 2700 years: a multi-proxy and multi-record approach, Clim. Past, 12, 849-869, https://doi.org/10.5194/cp-12-849-2016, 2016.

Colonese, A. C., Zanchetta, G., Fallick, A. E., Martini, F., Manganelli, G., and Lo Vetro, D.: Stable isotope composition of Late Glacial land snail shells from Grotta del Romito (southern Italy): paleoeclimatic implications, Palaeogeogr. Palaeocl., 254, 550560, 2007. 
Colonese, A. C., Zanchetta, G., Fallick, A. E., Manganelli, G., Lo Cascio, P., Hausmann, N., Baneschi, I., and Regattieri, E.: Oxygen and carbon isotopic composition of modern terrestrial gastropod shells from Lipari Island, Aeolian Archipelago (Sicily), Palaeogeogr. Palaeocl., 394, 119-127, 2014.

Dansgaard, W.: Stable isotopes in precipitation, Tellus, 16, 436468, 1964.

Day, C. C. and Henderson, G. M.: Controls on trace-element partitioning in cave-analogue calcite, Geochim. Cosmochim. Ac., 120, 612-627, 2013.

Dixit, Y., Hodell, D. A., and Petrie, C. A.: Abrupt weakening of the summer monsoon in northwest India $\sim 4100 \mathrm{yr}$ ago, Geology, 42, 339-342, 2014.

Drysdale, R., Zanchetta, G., Hellstrom, J., Fallick, A. E., Zhao, J., Isola, I., and Bruschi, G.: The palaeoclimatic significance of a Middle to late Pleistocene stalagmite from the Alpi Apuane karst, central-western Italy, Earth Planet. Sc. Lett., 227, 215-229, 2004.

Drysdale, R. N., Zanchetta, G., Hellstrom, J., Maas, R., Fallick, A. E., Pickett, M., Cartwright, I., and Piccini, L.: Late Holocene drought responsible for the collapse of Old World civilizations is recorded in an Italian cave flowstone, Geology, 34, 101-104, 2006.

Eshel, G.: Mediterranean climates, Israel J. Earth Sci., 51, 157-168, 2002.

Fairchild, I. J. and Baker, A.: Speleothem science: from process to past environments, 3rd Edn., John Wiley and Sons, Chichester, 2012.

Fairchild, I. J. and Treble, P.: Trace elements in speleothems as recorders of environmental change, Quaternary Sci. Rev., 28, 449-468, 2009.

Fairchild, I. J., Borsato, A., Tooth, A. F., Frisia, S., Hawkesworth, J., Huang, Y., McDermott, F., and Spiro, B.: Controls on trace element (SreMg) compositions of carbonate cave waters: implications for speleothem climatic records, Chem. Geol., 166, 255269, 2002.

Fairchild, I. J., Smith, C. L., and Baker, A.: Modification and preservation of environmental signals in speleothems, Earth Sci. Rev., 75, 105-153, 2006.

Finné, M., Holmgren, K., Shen, C. C., Hu, H. M., Boyd, M., and Stocker, S.: Late Bronze Age climate change and the destruction of the Mycenaean Palace of Nestor at Pylos, PlosOne, 12, e0189447, https://doi.org/10.1371/journal.pone.0189447, 2017.

Fletcher, W. J., Debret, M., and Sanchez Goni, M. F.: Holocene emergence of a low frequency millennial oscillation in western Mediterranean climate: implications for past dynamics of the North Atlantic atmospheric westerlies, Holocene, 23, 153-166, 2013.

Frisia, S. and Borsato, A.: Karst, Developments in Sedimentology, 61, 269-318, 2012.

Frisia, S., Borsato, A., Fairchild, I., and McDermott, F.: Calcite fabrics, growth mechanisms, and environments of formation in speleothems from the Italian Alps and southwestern Ireland, J. Sediment. Petrol., 70, 1183-1196, 2000.

Frisia, S., Borsato, A., Fairchild, I. J., McDermott, F., and Selmo, E. M.: Aragonite-calg relationships in speleothems (Grotte de Clamouse, France): environment, fabrics, and carbonate geochemistry, J. Sediment. Res., 72, 687-699, 2002.

Fyfe, R. M., Woodbridge, J., and Roberts, N.: From forest to farmland: pollen-inferred land cover change across Europe using the pseudobiomization approach, Glob. Change Biol., 21, 11971212, 2015.

Gaetani, M., Pohl, B., and Douville, H.: West African Monsoon influence on the summer Euro-Atlantic circulation, Geophys. Res. Lett., 38, 1-5, 2011.

Genty, D., Baker, A., Massault, M., Proctor, C., Gilmour, M., PonsBranchu, E., and Hamelin, B.: Dead carbon in stalagmites: carbonate bedrock paleodissolution vs. ageing of soil organic matter. Implications for ${ }^{13} \mathrm{C}$ variations in speleothems, Geochim. Cosmochim. Ac., 65, 3443-3457, 2001.

Giraudi, C.: The Apennine glaciations in Italy. Quarternary glaciations-extent and chronology, part I: Europe, Developments in Quaternary Science, 2, 215-224, 2004.

Giraudi, C.: Middle to Late Holocene glacial variations, periglacial processes and alluvial sedimentation on the higher Apennine massifs (Italy), Quaternary Res., 64, 176-184, 2005.

Giraudi, C.: Coarse sediments in Northern Apennine peat bogs and lakes: New data for the record of Holocene alluvial phases in peninsular Italy, Holocene, 24, 932-943, 2014.

Griffiths, M. L., Drysdale, R. N., Gagan, M. K., Frisia, S., Zhao, J. X., Ayliffe, L. K., Wahyoe, S. H., Hellstrom, J. C., Fischer, M. J., Feng, Y. X., and Suwargadi, B. W.: Evidence for Holocene changes in Australian-Indonesian monsoon rainfall from stalagmite trace element and stable isotope ratios, Earth Planet. Sc. Lett., 292, 27-38, 2010.

Hellstrom, J. C.: Rapid and accurate U-Th dating using parallel ion counting multi-collector ICP-MS, J. Anal. Atom. Spectrom., 18, 135-136, 2003.

Hellstrom, J. C.: U-Th dating of speleothems with high initial ${ }^{230} \mathrm{Th}$ using stratigraphical constraint, Quat. Geochronol., 1, 289-295, 2006.

Hellstrom, J. C. and McCulloch, M. T.: Multi-proxy constraints on the climatic significance of trace element records from a New Zealand speleothem, Earth Planet. Sc. Lett., 179, 287-297, 2000.

Hellstrom, J., Paton, C., Woodhead, J., and Hergt, J.: Iolite: software for spatially resolved LA-(quad and MC) ICPMS analysis, in: Mineralogical Association of Canada Short Course Series, edited by: Sylvester, P., Quebec, Canada, Vol. 40, 343-348, 2008.

Jackson, M. G., Oskarsson, N., Tronnes, R. G., McManus, J. F., Oppo, D. W., Grönvold, K., Hart, S. R., and Sachs, J. P.: Holocene loess deposition in Iceland: evidence for millennialscale atmosphere-ocean coupling in the North Atlantic, Geology, 33, 509-512, 2005.

Jalali, B., Sicre, M.-A., Bassetti, M.-A., and Kallel, N.: Holocene climate variability in the North-Western Mediterranean Sea (Gulf of Lions), Clim. Past, 12, 91-101, https://doi.org/10.5194/cp-1291-2016, 2016.

Jalali, B., Sicre, M. A., Kallel, N., Azuara, J., Combourieu-Nebout, N., Bassetti, M. A., and Klein, V.: High-resolution Holocene climate and hydrological variability from two major Mediterranean deltas (Nile and Rhone), Holocene, 27, 1158-1168, 2017.

Jiménez-Amat, P. and Zahn, R.: Offset timing of climate oscillations during the last two glacial interglacial transitions connected with large-scale freshwater perturbation, Paleoceanography, 30, 768788, 2015

Kim, S. T. and O'Neil, J. R.: Equilibrium and nonequilibrium oxygen isotope effects in synthetic carbonates, Geochim. Cosmochim. Ac., 61, 3461-3475, 1997. 
Lionello, P., Bhend, J., Buzzi, A., Della-Marta, P. M., Krichak, S., Jansà, A., Maheras, P., Sanna, A., Trigo I. F., and Trigo, R.: Cyclones in the Mediterranean region: climatology and effects on the environment, in: Mediterranean Climate Variability, edited by: Lionello, P., Malanotte-Rizzoli, P., Boscolo, R., Amsterdam, Elsevier, 324-272, 2006.

Lionello, P., Abrantes, F., Congedi, L., Dulac, F., Gacic, M., Gomis, D., Goodess, C., Hoff, H., Kutiel, H., Luterbacher, J., Planton, S., Reale, M., Schröder, K., Struglia, M. V., Toreti, A., Tsimplis, M., Ulbrich, U., and Xoplaki, E.: Introduction: Mediterranean Climate: Background Information, Elsevier, Amsterdam, 2012.

Longinelli, A., Anglesio, E., Flora, O., Iacumin, P., and Selmo, E.: Isotopic composition of precipitation in Northern Italy: reverse effect of anomalous climatic events, J. Hydrol., 329, 471-476, 2006.

López-Moreno, J. I., Vicente-Serrano, S. M., Morán-Tejeda, E., Lorenzo-Lacruz, J., Kenawy, A., and Beniston, M.: Effects of the North Atlantic Oscillation (NAO) on combined temperature and precipitation winter modes in the Mediterranean mountains: Observed relationships and projections for the 21 st century, Global Planet. Change, 77, 62-76, 2011.

Marino, G., Rohling, E. J., Rodriguez-Sanz, L., Grant, K. M., Roberts, A. P., Stanford, J. D., and Yu, J.: Bipolar seesaw control on last interglacial sea level, Nature, 552, 197-201, 2015.

Martrat, B., Jiménez-Amat, P., Zahn, R., and Grimalt, J.-O.: Similarities and dissimilarities between the last two deglaciations and interglaciations in the North Atlantic region, Quaternary Sci. Rev., 99, 122-134, 2014.

McDonald, J., Drysdale, R. N., Hill, D., Chisari, R., and Wong, H.: The hydrochemicalresponse of cave drip waters to sub-annual and inter-annualclimate variability, Wombeyan Caves, SE Australia, Chem. Geol., 244, 605-623, 2007.

McGinley, J. A. and Zupanski, M.: Numerical analysis of the influence of jets, fronts and mountains on Alpine lee cyclogenesis: More cases from the ALPEX SOP, Meteorol. Atmos. Phys., 43, 7-20, 1990.

Mickler, P. J., Stern, L. A., and Banner, J. L.: Large kinetic isotope effects in modern speleothems, Geol. Soc. Am. Bull., 118, 6581, 2006.

Morse, J. W. and Bender, M. L.: Partition coefficients in calcite: Examination of factors influencing the validity of experimental results and their application to natural systems, Chem. Geol., 82, 265-277, 1990

Mussi, M., Leone, G., and Nardi, I.: Isotopic geochemistry of natural waters from the Alpi Apuane-Garfagnana area, Northern Tuscany, Italy, Mineral. Petrograph. Acta, 41, 163-178, 1998.

Nieto, R., Gimeno, L., Drumond, A., and Hernandez, E.: A Lagrangian identification of the main moisture sources and sinks affecting the Mediterranean area, WEAS Transactions on Environment and Development, 5, 365-374, 2010.

Olsen, J., Anderson, N. J., and Knudsen, M. F.: Variability of the North Atlantic Oscillation over the past 5,200 years, Nat. Geosci., 5, 808-812, 2012.

Ortega, R., Maire, R., Devès, G., and Quinif, Y.: High-resolution mapping of uranium and other trace elements in recrystallized aragonite-calcite speleothems from caves in the Pyrenees (France): implication for U-series dating, Earth Planet. Sc. Lett., 237, 911-923, 2005.
Osmond, J. K.: Uranium series disequilibrium in hydrologic studies, in: Handbook of Environmental Geochemistry, edited by: Fritz, P. and Fontes, J. C., Elsevier, Amsterdam, 259-282, 1980.

Osmond, J. K. and Ivanovich, M.: Uranium-series mobilization and surface hydrology, Uranium-series disequilibrium: applications to earth, marine, and environmental sciences, 2nd Edn., Oxford Sciences Publications, Oxford, 1992.

Peyron, O., Magny, M., Goring, S., Joannin, S., de Beaulieu, J.L., Brugiapaglia, E., Sadori, L., Garfi, G., Kouli, K., Ioakim, C., and Combourieu-Nebout, N.: Contrasting patterns of climatic changes during the Holocene across the Italian Peninsula reconstructed from pollen data, Clim. Past, 9, 1233-1252, https://doi.org/10.5194/cp-9-1233-2013, 2013.

Piccarreta, M., Caldara, M., Capolongo, D., and Boenzi, F.: Holocene geomorphic activity related to climatic change and human impact in Basilicata, Southern Italy, Geomorphology, 128, 137-147, 2011.

Piccini, L., Zanchetta, G., Drysdale, R. N., Hellstrom, J., Isola, I., Fallick, A. E., Leone, G., Doveri, M., Mussi, M., Mantelli, F., Molli, G., Lotti, L., Roncioni, A., Regattieri, E., Meccheri, M., and Vaselli, L.: The environmental features of the Monte Corchia cave system (Apuan Alps, central Italy) and their effects on speleothem growth, Int. J. Speleol., 37, 153-172, 2008.

Pierre, C.: The oxygen and carbon isotope distribution in the Mediterranean water masses, Mar. Geol., 153, 41-55, 1999.

Railsback, L. B., Liang, F., Brook, G. A., Voarintsoa, N. R. G., Sletten, H. R., Marais, E., Hardte, B., Chen, H. E., and Edwards, R. L.: The timing, two-pulsed nature, and variable climatic expression of the $4.2 \mathrm{ka}$ event: A review and new high-resolution stalagmite data from Namibia, Quaternary Sci. Rev., 186, 78-90, 2018.

Rapetti, F. and Vittorini, S.: Carta climatica della Toscana centrosettentrionale, Pacini Editore, Pisa, 1994.

Reale, M. and Lionello, P.: Synoptic climatology of winter intense precipitation events along the Mediterranean coasts, Nat. Hazards Earth Syst. Sci., 13, 1707-1722, https://doi.org/10.5194/nhess-13-1707-2013, 2013.

Regattieri, E., Zanchetta, G., Drysdale, R. N., Isola, I., Hellstrom, J., and Roncioni, A.: A continuous stable isotopic record from Penultimaye glacial maximum on to the Last Interglacial (159$121 \mathrm{ka}$ ) from Tana Che Urla Cave (Apuan Alps, central Italy), Quaternary Res., 82, 450-461, 2014a.

Regattieri, E., Zanchetta, G., Drysdale, R. N., Isola, I., Hellstrom, J. C., and Dallai, L.: Lateglacial to Holocene trace element record (Ba, Mg, Sr) from Corchia Cave (Apuan Alps, central Italy): paleoenvironmental implications, J. Quaternary Sci., 29, 381-392, 2014b.

Regattieri, E., Giaccio, B., Zanchetta, G., Drysdale, R. N., Galli, P., Nomade, S., Peronace, E., and Wulf, S.: Hydrological variability over Apennine during the Early Last Glacial precession minimum, as revealed by a stable isotope record from Sulmona basin, central Italy, J. Quaternary Sci., 30, 19-31, 2015.

Regattieri, E., Zanchetta, G., Drysdale R. N., Isola, I., Woodhead, J. D., Helstromm, J. C., Giaccio, G. A., Baneschi, I., and Dotsika, E.: Environmental variability between the penultimate deglaciation and the mid Eemian: Insights from Tana che Urla (central Italy) speleothem trace element record, Quaternary Sci. Rev., 152, 80-92, 2016. 
Regattieri, E., Giaccio, B., Nomade, S., Francke, A., Vogel, H., Drysdale, R. N., Perchiazzi, N., Wagner, B., Gemelli, M., Mazzini, I., Boschi, C., Galli, P., and Peronace, E.: A Last Interglacial record of environmental changes from the Sulmona Basin (central Italy), Palaeogeogr. Palaeocl., 472, 51-66, 2017.

Regattieri, E., Zanchetta, G., Isola, I., Bajo, P., Boschi, C., Perchiazzi, N., Drysdale, R. N., Hellstrom, J. C., Francke, A., and Wagner, B.: A MIS 9/MIS 8 speleothem record of hydrological variability from Macedonia (F.Y.R.O.M.), Global Planet. Change, 162, 39-52, 2018.

Riotte, J., Chabaux, F., Benedetti, M., Dia, A., Gérard, M., Boulègue, J., and Etamé, J.: Uranium colloidal transport and origin of the ${ }^{234} \mathrm{U}-{ }^{238} \mathrm{U}$ fractionation in surface waters: new insights from Mount Cameroon, Chem. Geol., 202, 365-381, 2003.

Roberts, N., Stevenson, T., Davis, B., Cheddadi, R., Brewster, S., and Rosen, A.: Holocene climate, environment and cultural change in the circum-Mediterranean region, in: Past Climate Variability through Europe and Africa, edited by: Battarbee, R. W., Gasse, F., and Stickley, C. E., Developments in Paleoenvironmental Research, Vol. 6, Springer, Dordrecht, 2004.

Rohling, E. J., Marino, G., and Grant, K. M.: Mediterranean climate and oceanography, and the periodic development of anoxic events (sapropels), Earth-Sci. Rev., 143, 62-97, 2015.

Sabatier, P., Dezileau, L., Colin, C., Briqueu, L., Bouchette, F., Martinez, P., Siani, G., Raynal, O., and Von Grafenstein, U.: 7000 years of paleostorm activity in the NW Mediterranean Sea in response to Holocene climate events, Quaternary Res., 7, 1-11, 2012.

Samartin, S., Heiri, O., Joos, F., Renssen, H., Franke, J., Brönnimann, S., and Tinner, W.: Warm Mediterranean mid-Holocene summers inferred from fossil midge assemblages, Nat. Geosci., 10, 207-212, 2017.

Sarti, G., Rossi, V., Amorosi, A., Bini, M., Giacomelli, S., Pappalardo, M., Ribecai, C., Ribolini, A., and Sammartino, I.: Climatic signature of two Mid-Late Holocene fluvial incisions formed under sea-level highstand conditions (Pisa coastal plain, NW Tuscany, Italy), Palaeogeogr. Palaeocl., 424, 183-195, 2015.

Sinclair, D. J.: Two mathematical models of $\mathrm{Mg}$ and $\mathrm{Sr}$ partitioning into solution during incongruent calcite dissolution: implications for dripwater and speleothem studies, Chem. Geol., 283, 119133, 2011.

Tognarelli, A., Zanchetta, G., Regattieri, E., Isola, I., Drysdale, R. N., Bini, M., and Hellstrom, J. C.: Wavelet analysis of $\delta^{18} \mathrm{O}$ and $\delta^{13} \mathrm{C}$ time-series from an Holocene speleothem record from Corchia Cave (central Italy): insights for the recurrence of drywet periods in the Central Mediterranean, Ital. J. Geosci., 137, 128-137, 2018.

Treble, P., Shelley, J. M. G., and Chappell, J.: Comparison of high resolution subannual records of trace elements in a modern (1911-1992) speleothem with instrumental climate data from southwest Australia, Earth Planet. Sc. Lett., 216, 141-153, 2003.

Trigo, I. F., Bigg, G. R., and Davies, T. D.: Climatology of Cyclogenesis Mechanisms in the Mediterranean, Mon. Weather Rev., 130, 549-569, 2002.

Trouet, V., Esper, J., Graham, N. E., Baker, A., Scourse, J. D., and Frank, D. C.: Persistent positive North Atlantic oscillation mode dominated the Medieval Climate Anomaly, Science, 324, 78-80, 2009.
Tzedakis, P. C., Drysdale, R. N., Margari, V., Skinner, L. C., Menviel, L., Rhodes, R. H., Taschetto, A. S., Hodell, D. A., Crowhurst, S. J., Hellstrom, J. C., Fallick, A. E., Grimalt, J. O., McManus, J. F., Martrat, B., Mokeddem, Z., Parrenin, F., Regattieri, E., Roe, K., and Zanchetta, G.: Enhanced climate instability in the North Atlantic and southern Europe during the Last Interglacial, Nat. Commun., 9, 4235, https://doi.org/10.1038/s41467018-06683-3, 2018.

Weiss, H.: Megadrought, collapse, and resilience in late 3rd millennium BC Mesopotamia, in: 2200 BC A Climatic Breakdown as a Cause for the Collapse of the Old World?, edited by: Meller, H., Arz, H. W., Jung, R., Risch, R., Landesmuseum fur Vorgeschichte, Halle, 35-52 2015.

Weiss, H.: Global megadrought, societal collapse and resilience at 4.2-3.9 ka BP across the Mediterranean and west Asia, Clim. Chang. Cult. Evol. PAGES Mag., 24, 62-63, 2016.

Welc, F. and Marks, L.: Climate change at the end of the Old Kingdom in Egypt around 4200 BP: new geoarchaeological evidence, Quaternary Int., 324, 124-133, 2014.

Woodhead, J., Hellstrom, J., Hergt, J. M., Greig, A., and Maas, R.: Isotopic and elemental imaging of geological materials by laser ablation inductively coupled plasma-mass spectrometry, Geostand. Geoanal. Res., 31, 331-343, 2007.

Zanchetta, G., Drysdale, R. N., Hellstrom, J. C., Fallick, A. E., Isola, I., Gagan, M. K., and Pareschi, M. T.: Enhanced rainfall in the Western Mediterranean during deposition of sapropel S1: stalagmite evidence from Corchia cave (Central Italy), Quaternary Sci. Rev., 26, 279-286, 2007.

Zanchetta, G., Giraudi, C., Sulpizio, R., Magny, M., Drysdale, R. N., and Sadori, L.: Constraining the onset of the Holocene "Neoglacial" over the central Italy using tephra layers, Quaternary Res., 78, 236-247, 2012.

Zanchetta, G., Bini, M., Cremaschi, M., Magny, M., and Sadori, L.: The transition from natural to anthropogenic-dominated environmental change in Italy and the surrounding regions since the Neolithic: an introduction, Quaternary Int., 303, 1-9, 2013.

Zanchetta, G., Bar-Matthews, M., Drysdale, R. N., Lionello, P., Ayalon, A., Hellstrom, J. C., Isola, I., and Regattieri, E.: Coeval dry events in the central and eastern Mediterranean basin at 5.2 and $5.6 \mathrm{ka}$ recorded in Corchia (Italy) and Soreq Cave (Israel) speleothems, Global Planet. Change, 122, 130-139, 2014.

Zanchetta, G., Regattieri, E., Isola, I., Drysdale, R. N., Bini, M., Baneschi, I., and Hellstrom, J. C.: The so-called "4.2 event" in the central Mediterranean and its climatic teleconnections, Alpine and Mediterranean Quaternary, 29, 5-17, 2016.

Zanchetta, G., Bini, M., Giaccio, B., Manganelli, G., Benocci, A., Regattieri, E., Colonese, A. C., Boschi, C., and Biagioni, C.: Middle Pleistocene (MIS 14) environmental conditions in the central Mediterranean derived from terrestrial molluscs and carbonate stable isotopes from Sulmona Basin (Italy), Palaeogeogr. Palaeocl., 485, 236-246, 2017.

Zanchetta, G., Bini, M., Di Vito, M. A., Sulpizio, R., and Sadori, L.: Tephrostratigraphy of paleoclimatic archives in central Mediterranean during the Bronze Age, Quaternary Int., https://doi.org/10.1016/j.quaint.2018.06.012, online first, 2018.

Zappa, G., Hawcroft, M. K., Shaffrey, L., Black, E., and Brayshaw, D. J.: Extratropical and projected decline of winter Mediterranean precipitation in the CMIP5 models, Clim. Dynam., 45, 1727-1738, 2015. 
Zhornyak, L. V., Zanchetta, G., Drysdale, R. N., Hellstrom, J. C., Isola, I., Regattieri, E., Piccini, L., and Baneschi, I.: Stratigraphic evidence for a "pluvial phase" between ca. 8200-7100 ka from Renella Cave (Central Italy), Quaternary Sci. Rev., 30, 409-417, 2011. 